\title{
Correction to: Computation of Fisher-Gale Equilibrium by Auction
}

\author{
Yurii Nesterov $^{1,2} \cdot$ Vladimir Shikhman $^{3}$
}

(C) The Author(s) 2018, corrected publication June 2018

\section{Correction to: J. Oper. Res. Soc. China https://doi.org/10.1007/s40305-018-0195-5}

The article "Computation of Fisher-Gale Equilibrium by Auction", written by Yurii Nesterov and Vladimir Shikhman, was originally published electronically on the publisher's internet portal (currently SpringerLink) on 16th February 2018 without open access. With the author(s)' decision to opt for Open Choice, the copyright of the article changed on 12th June 2018 to (C) The Author(s) 2018 and the article is forthwith distributed under the terms of the Creative Commons Attribution 4.0 International License (http://creativecommons.org/licenses/by/4.0/), which permits use, duplication, adaptation, distribution and reproduction in any medium or format, as long as you give appropriate credit to the original author(s) and the source, provide a link to the Creative Commons license and indicate if changes were made.

Open Access This article is distributed under the terms of the Creative Commons Attribution 4.0 International License (http://creativecommons.org/licenses/by/4.0/), which permits unrestricted use, distribution, and reproduction in any medium, provided you give appropriate credit to the original author(s) and the source, provide a link to the Creative Commons license, and indicate if changes were made.

The original article can be found online at https://doi.org/10.1007/s40305-018-0195-5.

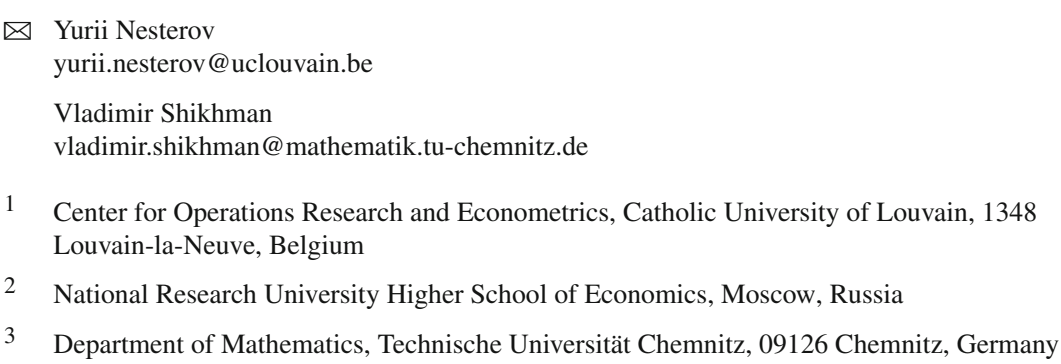

